\title{
Participatory Politics, Environmental Journalism and Newspaper Campaigns
}

\section{Anita Howarth}

\begin{abstract}
This article explores the extent to which approaches to participatory politics might offer a more useful alternative to understanding the role of environmental journalism in a society where the old certainties have collapsed, only to be replaced by acute uncertainty. This uncertainty not only generates acute public anxiety about risks, it has also undermined confidence in the validity of long-standing premises about the ideal role of the media in society and journalistic professionalism. The consequence, this article argues, is that aspirations of objective reportage are outdated and illequipped to deal with many of the new risk stories environmental journalism covers. It is not a redrawing of boundaries that is needed but a wholesale relocation of our frameworks into approaches better suited to the socio-political conditions and uncertainties of late modernity. The exploration of participatory approaches is an attempt to suggest one way this might be done.
\end{abstract}

Keywords: campaign, environment, GM food, participatory politics, risks 


\section{Introduction}

It only makes sense to redraw the boundaries between journalism's established demarcations of objective versus polemical journalism, and reportage versus commentary if the premises underpinning these concerning the ideal role of the media in society and journalistic professionalism are considered valid. This article argues that this is not the case: that aspirations of objective reportage are outdated and ill-equipped to deal with many of the new risk stories environmental journalism covers. It is not a redrawing of boundaries that is needed but a wholesale relocation of our frameworks into approaches better suited to the socio-political conditions of late modernity.

The roots of current Anglo-American journalistic ideals and practices lie in the emergence of classic liberalism during the Age of Revolution of the $18^{\text {th }}$ and $19^{\text {th }}$ centuries where, on the one hand, there was concern about the power of the press to create political stability or foment civil unrest. On the other hand, there was considerable enthusiasm and optimism about the prospect of societal "progress" from the new methods and inventions of the scientific-industrial revolution. What emerged were ideas about the democratic role of the press as a watchdog against the abuses of corrupt politicians whose excesses risked inciting civil unrest, the provider of accurate information necessary for an informed public and a forum for critical-rational debates that provided a necessary safety valve for tensions in society and communicating the wishes of the public to government (see Scammell \& Semetko, 2000). The professional mechanisms for delivering these - neutrality, "objectivity" and commitment to factual accuracy - came, over the next 250 years, to be seen as the defining qualities of the "professionalism" necessary to meet the "higher goals" and "duties" to democracy (Scammell \& Semetko, 2000). The supposed output of this professionalism was an "objective journalism 'of record' that [drew] on authoritative sources to provide reliable information of matters of significance" (McQuail, 2000, p. 32). Conversely, certain types of polemical writing in certain places and at certain times could then be criticized and dismissed as an unprofessional debasing of these ideals and potentially irresponsible because of the potential power of the press to incite public sentiment and to destabilize the political system (see Scammell \& Semetko, 2000). Thus, the preoccupation with "objective" reporting is a historical one rooted in notions of what is needed for a stable society.

As Scammell \& Semetko note, what is "curious" is that this classic view, rooted as it is in historical assumptions about political stability and societal progress, and the ideal roles of the press and the conduct needed to ensure this, has continued to "dominate so much thinking about the modern media" despite substantial societal changes since its origins and despite the rejection of classic liberalism by political theorists as "outdated" (2000, p. xii). Notwithstanding these critiques, dominant strands in journalism studies have remained pre-occupied with questions of how, why and with what implications current journalism practice falls short of the ideal (see, for instance, the debates on the "crisis of communication", Blumler \& Gurevitch, 1998).

Environmental journalism, however, exposes the inadequacies of these types of evaluations and of traditional polarizations between objective and polemical writing, reportage and commentary. It is able to do this because much of its subject material is concerned with new risks - oil spills, GM food and crops, nuclear power, climate change - where classic demarcations in journalism collapse, not because of unprofessional practices but because of the nature of the debates. These debates are characterized by scientific disputes over evidence, knowledge and facts so any 
notion of "objectivity" in science and the "objective" reporting of this by journalists becomes oxymoronic.

The challenge for journalists is that disputes about knowledge in conditions where there is no clear evidence of harm and no clear evidence of safety are abstract, remote from the public and couched in scientific or academic jargon that renders them inaccessible to a lay audience and to many journalists (see Kitzinger, 1997, Hargreaves \& Lewis, 2008). However, when basic essentials - food, air, water - are implicated, otherwise esoteric debates become directly relevant to the public and so legitimate subject matter for journalists. The challenge is how to make the esoteric accessible to a lay readership and here visual images of dying fish (Beck, 1986), metaphorical spectres of disaster such as "Frankenstein foods", or parallels with other scares can play a crucial role (see Howarth, 2012). When journalists are able to make these connections the media can cast the "spotlight" on new risks and their relevance for readers (Beck, 1986). When the risks impinge on life-sustaining activities, implicate individual decisions on what to eat or drink and are located in the wider context of a history of government mismanagement of food scares (Howarth, 2012), then strong public emotions such as fear and anxiety become reasonable rather than irrational responses to perceived threats. However, the classic liberal emphasis on rational debate, objective reporting and factual accuracy undermines the capacity of journalists to articulate these without being accused of sensationalism.

It was in this context that four national newspapers in Britain launched campaigns on GM food with the agenda of "revealing the hidden facts in food", educating the public about these and advocating policy change. The response of the then Prime Minister Tony Blair to these campaigns was to denounce them as "sensationalist", fictionalized campaigns of "misinformation" (Blair, 1999). When he resigned eight years later Blair claimed that journalistic "accuracy" had become "second to impact"; that "rather than just 'report' news", journalists were now providing "interpretation"; and that the old boundaries between news and commentary, fact and opinion had blurred (2000). In so doing, Blair drew on classic liberal assumptions about the ideal role of the media in society, the professional practices that are said to underpin this and the nature of the media-state relationship.

However, as argued above, these assumptions make little sense when the subject matter of environmental journalism is concerned with new risks. Aspirations of journalistic "objectivity", accuracy and neutral reportage infused from an era of authoritative science are incompatible with conditions of radical uncertainty where knowledge itself is disputed, the facts are contested, debates are highly polarized, policy elites are not trusted to act in the public interest and new moral discourses are emerging about consumer rights and agency.

This article explores the extent to which approaches to participatory politics might offer a more useful alternative to understanding the role of environmental journalism in a society where the old certainties have collapsed, only to be replaced by acute uncertainty. It then applies this to a discourse analysis of the editorials on GM food in four newspapers that campaigned against it and explores the extent to which assumptions about participatory politics might be more useful than the classic liberal premises about the role of the media in acting as a watchdog, providing "quality" of information and facilitating debate.

\section{Classic Liberalism, the Age of Revolution and Science}


The classic liberal view of democracy and the role of the media emerged in response to particular historical conditions and fears. In $18^{\text {th }}$-century America, it appeared in the argument of James Madison, writing in the midst of fears that civil war could tear apart the new republic (see Kaminsky, 2006), for the constitutional protection of freedom of expression as a necessary "safety valve" for the expression of diverse views and hence a mechanism for political stability. Across the Atlantic it appeared in the writings of $\mathrm{J}$. S. Mill amid anxiety that the wave of revolutions sweeping Europe could spread to Britain if the media were not free to expose and so check the abuses of corrupt politicians before they could incite civil unrest. The free press was therefore seen as an essential outlet for pent up frustrations and the confining of the "enormities of the revolution" (Mill, cited in Hargreaves, 2003, p. 44).

However, revolution was not only political but also scientific and technological. There was much enthusiasm about what innovations might mean for societal "progress" and this infused notions of an emerging profession of journalism. Thus, Mill argued that free expression "is fundamental not only to political freedom, but to society's ability to gather knowledge empirically and so to progress scientifically and in other domains" (cited in Hargreaves, 2003, p. 44). Thus from an early stage in the development of the core tenets of classic liberalism, fundamental links were made between press freedom, public opinion and mechanisms for political stability and progress.

Enthusiasm for the scientific revolution also informed notions about the kinds of news gathering methods deemed most appropriate. Here writers such as Mill drew on two separate strands of thinking: the valuing of scientific method - the application of the rational mind to the dispassionate observing of a phenomenon in order to accumulate objective, factual and reliable knowledge - and fear of those forms of speech which could incite protests, civil unrest and cause harm. The ability of scientific methods to deliver unitary, objective and authoritative science (Locke, 2001; Yearley, 1991) and deliver a dispassionate, impartial account of what was observed were therefore seen by Mill and others as also capable of delivering objective journalism that served the higher ideals of stable democracy and political order. Thus the principles of scientific method were distilled into notions of what constituted professional conduct, practice and its contribution to society (McQuail, 2000).

Notwithstanding the persistence of discourses of "objectivity" in debates about journalistic standards the concept has been poorly defined (McQuail, 2000; Schudson, 2001) largely because it has been divorced from these historical origins and partly because of the desire of journalists to deliver believable accounts of what happened (see Schudson, 2001; Mindich, 2000). Objectivity, when applied to journalism, was taken to mean a pseudo-rational style of writing which claimed to be an unemotional, impartial and accurate reporting of the facts (Mindich, 2000: 8). In providing this, journalists would not only provide the information the public needed to make political decisions on who to vote for they would also be able to stand as watchdogs, offering a disinterested, dispassionate and independent scrutiny of the abuses of those in political power. This did not mean opinion pieces were excluded from newspapers, but they were carefully located within a layout that ensured clear distinctions between objective journalism and polemical pieces, reportage and editorial opinion (see Schudson, 1978). Even then any overt advocacy tends to provoke fierce debate within journalistic circles (see Neuzil, 2008). 
In Britain, these divisions are not absolutes. During elections national newspapers openly declare support for one or other party and then claim they influenced the outcome (see Thomas, 2006). More important, however, for this article is a century-old tradition of a "campaigning press" (Birks, 2009; Greenslade, 2004) and the construction of newspaper identities around what is openly an endeavour in polemics and advocacy (see Conboy, 2006). However, this historicallyrooted co-existence of objective and polemical roles in the same newspapers has remained one of the largely unexplored paradoxes in British newspapers primarily because of the persistence of classical liberal paradigms. ${ }^{1}$ When viewed through the prism of these ideals such campaigns signify to critics a debasing of the higher ideals of "objective" journalism and its role in contributing to "rational" debate. When viewed through the prism of new risk-type environmental stories such overt partiality can be justified through an over-arching public interest evoked by the "potentially politically catastrophic" consequences of the advances of late modernity (Beck, 1986). An alternative framework is needed to address the paradox of co-existing objective and polemical ideals.

However, before exploring one such possibility it is worth reflecting on the persistence of classic liberalism and its associated notions of journalistic objectivity. Notwithstanding the discrediting of objective and impartial journalism as a "myth" (Schudson, 1978) with the "lynching" of African-Americans in the 1890s (Mindich, 2000) and media coverage of the McCarthy era (Cunningham, 2003), it has persisted. These cases may have discredited the notion but they failed to undermine the broad valuing of the "scientific method" and the ideals associated with it. Schudson suggests these persisted because journalists continued to believe them; they "wanted to, needed to, were forced by ordinary human aspiration to seek escape from their own deep convictions of doubt and drift" (1978, p. 21). However, the pervasive, radical uncertainty of new risks (see Beck, 1986) challenges the ability of journalists to "escape" when dealing with topics such as climate change, GM food and crops, etc. If objective, authoritative science is not possible when the evidence is contested, facts are disputed and the method of knowledge construction are the subject of disagreements; it then becomes difficult to see how it is possible to have objective, impartial and factually accurate reporting of these. In this context, the persistent adherence in journalism studies to the tenets of objectivity, impartiality and factual accuracy within classic liberalism needs to be questioned, not least because of its "taking for granted" of a narrow view of the roles of the media then using this to "provide the premises" for "virtually all avenues of inquiry" (Scammell \& Semetko, 2000 , p. xii), including questions of professional output.

There is a variety of $20^{\text {th }}$-century theories of democracy that offers alternatives and there is an urgent need for journalism studies to explore these. The caveat, though, is that $20^{\text {th }}$-century alternatives to classic liberalism "rarely focus on the mass media", so it is necessary to "tease out inferences" for the media and for journalism (Scammell \& Semetko, 2000).

\footnotetext{
1 Studies of American cases have attempted to explore the continuing tensions between environmental journalism, objectivity and campaigns (see Neuzil, 2008; Neuzil \& Kovarik, 1996). However, they are of limited use here for two reasons. First, they do not specifically address the epistemological conundrums posed by the concept of objectivity within new risk debates to the subject matter of journalism. Second, their notion of campaign is assumed to be self-evident so poorly defined and analytically vague. The consequence is that distinctions are made between mainstream and specialist media campaigns but not between ones where the reader infers the publication is campaigning and one where the editors self-label this.
} 


\section{The Alternative Offered by Participatory Approaches to Politics}

Participatory approaches to politics and democratic theory tend to ignore the media (Scammell \& Semetko, 2000 p. xxxvii); however, it is possible to adapt some of their principles (see Teorell, 2006) to outline the role and activities the traditional media may play in such approaches.

First, participatory approaches argue that political apathy in mature democracies is a hallmark of public disillusionment, alienation and disengagement with the conduct and relevance of politics for individual citizens (see Pateman, 1985; Teorell, 2006). The revival of democracy, they argue, lies in the valuing of political participation as an "end in itself" and not merely as a means to an end, for instance with the electing of new leaders, as classic liberal approaches have tended to assume (Scammell \& Semetko, 2000; Teorell, 2006). This facilitates a more expansive notion of participatory activities that legitimizes many diverse forms of environmental protest. It also means repositioning the media, not as the dispassionate and impartial observers of classic liberalism, but as key, active and engaged participants in political debate with the potential to enhance public participation through educating, informing, etc. The media can therefore play a crucial role in realizing the value of participation as an "end" in itself; so the key questions then are not the quality of media participation but the existence of the participation, the potential it has for expanding the participation of others and the means by which they are able to do this. Rather than fearing the potential for the media to incite resistance and civic unrest, as classic liberalism tends to do, participatory approaches value this potential as a legitimate "end" in itself and as a means of revitalizing public participation, for instance in environmental protests in mature democracies characterized by political apathy.

Second, participatory theorists such as Pateman (1985) challenge assumptions that individuals are "free and equal" in liberal democracies and argue that the formal or legal existence of certain rights is of limited value if they do not translate into practical choices in everyday life (see also Held, 2006). This means that the site of struggle therefore is the lived experience of here and now, not possible choices at the next election. It also means that claims about existing relationships need to be examined in order to assess whether freedoms are operating in practice.

Third, Teorell (2006) includes discussion as a form of participatory activity. Liberal and deliberative models of democracy (see Dryzek, 2006; Habermas, 1989 (1962), 1992) have long afforded the media a key role in the public sphere where diverse viewpoints are articulated in critical-rational debates, collated into a consensus about collective opinion and then transmitted to governments. The problem with this framework is that emotive discourses are not only anathema to critical-rationalists but also the antithesis of apathy and a key component in political engagement and mobilization. The denial of the legitimacy of such discourses within the public sphere signifies an "emotional deficit" in these approaches (see Richards, 2006), but their inclusion provides politicians with the means to discredit certain types of newspaper coverage as "irrational" or "sensationalist" (see Blair, 2007). Participatory approaches do not de-legitimatize emotion in politics, so it becomes possible to interweave both feelings and reason within what may be considered legitimate or credible public discussion. The other problem with liberal and 
deliberative approaches to discussion is their concern with the formation of a consensus in which certain views can be excluded, marginalized or silenced within claims of a "majoritarian" consensus. The assumption in participatory approaches is that there will be a multiplicity of perspectives, articulated in multiple forums; even when one side loses the policy debate the final decision can still have legitimacy if the different sides of an argument have been heard. So it is not the type of discourse, consensus formation or the influence on the decision that confers legitimacy but participation and the arrival at a decision through the consideration of different views that matters (Teorell, 2006 p. 797).

The fourth type of participatory activity, that of "influencing attempts" (Teorell, 2006 , p. 788), is arguably the most controversial when applied to journalism and offers one way of addressing the objectivity-polemics paradox in Britain's campaigning newspapers. Self-labelled campaigns are deliberate, explicit attempts to change the direction of government policy. That is, they signify the intentional shift in a newspaper from assumptions of "impartial" or "objective reporting" to advocacy and to mobilize the public (see Howarth, 2012). Locating these forms of newspaper engagement within participatory approaches means that rather than campaigns being dismissed as deviations from professional standards or remaining silent on what they say about journalism it becomes possible to consider them as legitimate forms of participatory politics. In which case, partiality becomes acceptable.

The analysis in this article applies these four principles to newspaper engagement with GM food and crops - a new risk domain in which government assumptions about objectivity and certainty were increasingly challenged.

\section{New Risks, Food Scares and Distrust of Government - Challenges to Objectivity and Certainty}

The central contention here is that classic liberal assumptions about the press and objective journalism are outdated in late modernity. The reporting of GM food and crops illustrates this well.

Societal disputes in Britain over GM food and crops came to embody typical new risk debates. New risks are qualitatively different from natural disasters or controllable man-made risks in that they are manufactured through the advanced technological processes of late modernity, and their potential consequences are unknown and potentially unlimited (Beck, 1986 (1992), 1999; Giddens, 1998). However, the disputes over new risks are essentially over knowledge, what counts as evidence and what method may be most appropriate for determining evidence, whether there is evidence of harm, and whether, in the absence of evidence of harm, it can be assumed the new technologies are safe. In other words, scientific uncertainty and conflict exists at every level of these disputes. The idea that certainty can be derived from objective, authoritative science and the accumulation of more knowledge becomes meaningless when even the methods of achieving the knowledge are disputed by scientists (see Pusztai, 2002).

The potential for acute public uncertainty and heightened anxiety lies in the pervasiveness and proximity of the threats that new risks such as GM food and crops are seen to pose to everyday life-sustaining activities through the contamination of air, food, water, etc. (Beck, 2003; Giddens, 1998). However, they are also seen as undetectable to the naked eye, so ordinary people are powerless to take evasive action unless GM products are labelled as such. Governments, rather than protecting the public, are seen to be complicit through policies that encourage 
the expansion of the new technologies but are unable to limit the possible adverse impacts because knowledge is too limited (Beck, 2003; Giddens, 1998).

Beck (1986) argues that the media have a central role to play here in "spotlighting" the risks, exposing the scientific disputes over evidence to the public gaze and challenging the decisions of government to subject ordinary people to risks they cannot manage for want of adequate knowledge (Beck, 1986; see also Cottle, 1998). That is, the role of the media is to expose fallacious claims of objective, authoritative science, but they cannot do so through claims of counter-objectivity because the very nature of knowledge and the methods of acquiring it are in dispute. Furthermore, the news media are "ill designed" to cover stories about such environmental risks and debates partly because the disputes are about highly abstract, technical, futuristic risks (Kitzinger, 1997, p. 320) and partly because of a pre-occupation with objectivity, factual accuracy and impartiality - the legacy of classic liberal assumptions about journalistic professionalism. What made GM food and crops particularly difficult for journalists was the absence of deaths, of incontrovertible evidence of harm or any visual evidence of contamination. While news routines usually rely on the concrete, the actual and the visual, GM food and crops presented journalists with debates about the abstract, hypothetical and invisible.

The first two principles of a participatory media - widening engagement and highlighting issues of everyday relevance and disempowerment - are particularly useful here. As newspaper engagement with GM food issues intensified, retailers claimed there had been a marked fall in sales of GM foods that culminated in a de facto consumer boycott (Howarth, 2010). School and work canteens banned GM food, GM crop fields were trashed, individual consumers staged protests in shops and a series of legal suits by individual farmers and consumers were brought against the big agribusiness companies for contamination of their farmland. Within weeks of the launch of campaigns against policy by four newspapers a de facto retailer boycott joined the consumer one. A participatory approach could argue that the issue here was not whether these newspaper responses were rational or whether direct causal effects linking media, specific behavioural actions and policy change can be proved, but the ability for increased newspaper engagement to mobilize public engagement and their willingness to become active, partisan and overt participants in policy debates.

The second principle was most clearly evident in that the new risks implicated food and everyday staples such as bread that everyone was consuming. One of the key issues was the extent to which consumers were able to choose whether or not to consume GM food. The government claimed it had introduced mandatory labelling (Blair, 1999); consumer and environmental NGOs argued that this applied to a very small proportion, that $60 \%$ of the food on supermarket shelves containing GM ingredients were unlabelled (Austin, 1999). This was to become a core plank in newspaper opposition to GM policy, but in order to mount such an opposition, facilitate discussion and attempt to influence policy journalists needed to overcome the abstract, hypothetical nature of the subject matter and address the collapse of the argument for scientific objectivity.

\section{The Analysis of Campaigns against GM Food and Crops}

Given these professional challenges it is hardly surprising that initial newspaper coverage of GM food and crops was sporadic, fragmentary and 
contradictory despite a decade of food scares including BSE/CjD (Howarth, 2010). It was only when direct parallels were drawn between BSE/CjD and the cultural/metaphoric discourses of "Frankenstein foods" and human "guinea pigs" were routinely used that journalists were able to engage more fully with the debates. The following analysis explores how these links were made, entrenched and challenged by four critical interventions - Prince Charles and Professor Árpád Pusztai in mid-1998, then the launch of the campaigns by the end of February 1999 and Blair's counter-attack on these. This rare direct criticism of the newspapers by a prime minister was based on classic liberal assumptions and ideals about objective, factually accurate reporting. The newspapers' justifications and defence of these campaigns articulated the fallacies in these assumptions. Presented with this polarization, the analyst is left with a choice - either the newspaper campaigns were an aberration, a deviation from professional standards of objective, impartial journalism, or these notions are inadequate for addressing what is the professional responsibility of journalism when dealing with new risks and escalating public resistance to these. This article subscribes to the latter perspective and argues that an alternative view of the role of the media is needed; it here draws on participatory approaches to democracy in particular newspapers roles in "influencing attempts" of public and government - and in "discussion".

This article defines newspaper campaigns as: (1) the conscious editorial decision by a particular newspaper directly and explicitly to intervene in a policy debate with the stated intention of influencing policy change or mobilizing public opposition to policy; (2) the self-labelling of this form of intervention as a "campaign" and the justification of this departure from what critics would claim was the role of "objective" or "impartial" purveyors of information (Howarth, 2012). The discourse analysis that follows focuses on the four newspapers that launched such campaigns. Critics could argue that this is self-defining; however, the counter-argument is that the approach taken in this article is informed by the premises of participatory politics and so privileges a focus on campaigns as a particular form of media participation. Furthermore, the four titles spanned the ideological and demographic reach of British newspapers from the centre right Daily Mail and the pro-Blair Express, which dominated the growing and politically significant mid-market (Greenslade, 2004); the Independent on Sunday, which was pro-environment and pro-business on regulatory issues while also claiming to be "independent" of party and commercial interference; and the Mirror, which was a working class, pro-Labour title. (For more on these ideological predispositions see Greenslade, 2004 and evidence given by editors to various parliamentary select committees.)

Even while restricting the focus to the four campaign titles, a Nexis news search between 1998 and 2000 delivered over 4,000 articles, so the discourse analysis was restricted to editorials. Editorials are widely accepted as a legitimate forum for the routine and explicit articulations of "the opinion of the newspaper" on an issue (Richardson \& Lancendorfer, 2004, pp. 75, 80), sites where newspapers "make use of their right to present themselves as autonomous actors" (Eilders, 2002, p. 26; Firmstone, 2008, pp. 2-3). This opinion explicitly interprets the issues of the day in terms of the particular ideology, values and positioning of the newspaper (Van Dijk, 1996). It also provides a forum in which editors can directly address particular audiences, such as policy elites, and defend any criticisms of their coverage (Henry \& Tator, 2002; Izadi, 1997, p. 141). Editorials are thus the one place where the newspaper's constructions of its participatory roles are likely to be most explicitly articulated as well as justified. In articulating the newspaper's position on an issue, 
editorials also serve as an organizing fulcrum around which the tone and content of news stories will be structured. While alternative viewpoints may well be given space, the dominant position across all the pages should broadly reflect the editorial policy articulated in these columns. The analysis of the editorials focused on themes of science, evidence and risk/benefit as dominant issues in new risk debates (see Beck, 1986) and they were analyzed at the four critical junctures identified above.

\section{The Critical Interventions of Prince Charles and Professor Pusztai}

Between the launch of Europe's first GM food in 1996 and June 1998, newspaper engagement with the issues was sporadic, fragmentary and ambivalent, with newspapers unsure whether to focus on benefits or risks of the novel food technology. This first changed in June 1998 with the publication of a letter by Prince Charles in the Daily Telegraph. In this he questioned the "rapid" expansion of GM food, articulated moral doubts about such an invasive technology, expressed lay scepticism about government reassurances about safety and raised the prospect of parallels with BSE/CjD. The mid-market Express and Daily Mail hailed this unprecedented intervention by the heir to throne as morally "right" in that the Prince was voicing the lay doubts and "fears" of the "vast majority" of ordinary people about "undue haste" in expanding GM food and crops (Daily Mail, 1998a).

Two months later a television documentary included preliminary research by Professor Pusztai claiming links between GM potatoes and "stunted" growth and reduced immunity in laboratory mice that were fed this produce. All four newspapers hailed Pusztai as an "independent" scientist, an expert-consumer whose own research caused him to question government certainty claims about safe food, whose moral doubts led him to question the "testing" of GM food on "human guinea pigs" and whose personal preference to avoid eating GM food was blocked by inadequate labelling policy (see Express, 1998a; Daily Mail, 1998a).

The interventions of Prince Charles and Pusztai marked significant shifts in the newspapers from ambivalence to hostility. What emerged was a very powerful discourse of moral doubts, scientific uncertainty and consumer disempowerment. While Pusztai's "revelations" were seen as challenging the certainty claims of government about safe food, they did not replace these with certainty claims of harm (Express, 1998a; Daily Mail, 1998a). The findings were inconclusive in that they did not "prove" that there would be the same effects in humans (Daily Mail, 1998a). Thus, scientific uncertainty was constructed as the absence of incontrovertible evidence of safety or of harm, of benefit or risk - that is, a state of suspended certainty and unknowing (see Daily Mail, 1998a; Express, 1998a).

The myth of objective, authoritative and unitary science collapsed in the face of conflict between scientists about what constituted credible and robust scientific methods for evaluating risk. These otherwise abstract debates were concretized in familiar foodstuffs such as bread and pizza, in parallels with government mismanagement of the contested science of BSE/CjD, in other food scares in the "history of manufactured food" such as pesticides, steroids, etc., and in cultural mythologies of "Frankenstein foods" and human "guinea pigs" (Daily Mail, 1998b; Express, 1998c; Mirror,1999). Thus very emotive discourses emerged out of the vacuum of suspended scientific certainty and the collapse of claims of objectivity and rationality. The deep anxiety generated by this was given added traction by a moral disquiet in "tampering" with life (Daily Mail, 1998a) and claims about the failure of government policy to ensure proper segregation of GM and non-GM, newspapers 
claimed, meant a contamination of the natural, the inability of retailers to label properly and the denial of consumer choice (Daily Mail, 1998b; Express, 1998c; Mirror 1999).

The subsequent treatment of Pusztai was seen as vindication of his "whistleblowing" argument. In the months after his intervention he was seen as the "independent scientist" of international standing (Express, 1998d), unaffected by political agendas that would subvert science, possessing the courage to raise "serious doubts" about GM food (Harrison, 1998) and "expose" food risks despite considerable professional and personal cost (Express, 1998d). Pusztai's employers at the Rowett Institute suspended him, claiming he had "drastically" misled the public by releasing premature findings based on a flawed methodology, banned him from speaking and then sought to discredit his work (Ingham, 1998). This was seen by the newspapers and other scientists as an attempt to "suppress" research that questioned the agenda of government and biotechnology companies.

\section{The Launch of the Campaigns}

The campaigns were a deliberate and self-conscious shift on the part of editors from classic liberal assumptions about "impartial reporting" to participatory arguments about the legitimacy of seeking to mobilize the public and influence policy in conditions of acute uncertainty, overwhelming public interest and the undemocratic tendencies of the government.

The Express had been the first to launch a campaign in July 1998 soon after the intervention of Prince Charles. The other three newspapers followed suit, but only after the government had rejected calls from its statutory advisor English Nature for a moratorium on the commercial cultivation of GM crops (Meacher, 1998). The campaigns were based on a tripartite agenda. First, they comprised a revelatory agenda intended to "bring out the facts" about the "hidden dangers" in food (Express, 1998b) and to "alert the public" to the dangers of "Frankenstein food" (Daily Mail, 1999). Second, an educative agenda set out to address gaps in consumer awareness about the lack of choice over whether or not to eat GM food (Daily Mail, 1999; Express, 1998b). Third, an advocacy agenda called for a change of policy in the form of comprehensive labelling and a moratorium on the commercial cultivation of GM crops (Daily Mail, 1999; Express, 1998b; Independent on Sunday, 1999; Mirror, 1999).

These three agendas combined in mutually reinforcing ways. For instance, the first two drew on assumptions that information facilitates participation, agency and power, and so holds the potential to mobilize consumers to resist policies that they disagreed with. This potential was that much greater given the readership and ideological spread to which these newspapers could appeal. This in turn could add to the credibility of the newspapers' advocacy agenda with its dual objectives of labelling and a moratorium. Thus the campaign agenda clearly articulated participatory endeavours to mobilize readers and influence policies.

The newspapers justified this departure from prevalent assumptions about newspaper behaviour in criticisms of government mishandling of the crisis and "lack of leadership" (Express, 1999) and the prospect of repeating the mistakes of BSE/CjD with GM food. The determination to press ahead with policy was not seen as strength but as "surreal" (Daily Mail, 1999) and "incomprehensible" (Mirror, 1999). The "explosive" rate of development was juxtaposed against the frightening spectre of suspended certainty, where there was evidence of neither safety nor harm; what 
"relatively little research" that had been done had "disclosed widespread possible risks" while simultaneously failing to "disclose the exact nature of risk" (Independent on Sunday, 1999). In this confusion, it was seen as irresponsible, irrational and illogical for government to press ahead. The time taken to gather the necessary "evidence", it was argued, could mean it would be "too late" to reverse any "malign effects" (Express, 1999). The papers claimed that the "real" policy agenda was not public interest, but as with BSE/CjD a "supine" support for commercial interests and "arrogance" (Daily Mail, 1999). The treatment of consumers as "guinea pigs without their knowledge" (Ingham ,1998c) and the "foisting" of such food and crops on the public was presented as immoral and irresponsible (Daily Mail, 1999). Instead of being responsive to the public, ministers were seen as "blithely indifferent" to the genuine and legitimate concerns of "millions of British consumers" (Daily Mail, 1999). In pushing ahead with a policy despite the "lack of consumer enthusiasm" (Independent on Sunday, 1999) and perceived preference of readers - "don't mess with nature" and "we want ... GM food cleared from the shelves immediately" - it was seen as acting without a democratic mandate.

\section{Blair Counter-Attacks}

Within days of the launch of the fourth newspaper campaign, Tony Blair launched a rare counter-attack in an article in the Daily Telegraph (1999). He accused "parts of the media" of "scaremongering" and claimed that the campaigns signified a sudden and frenzied collective flight from rationality (a "stampede") and transformation of fact into fiction ("great GM food saga"). He counter-argued that the "extraordinary campaign of distortion" was misrepresenting or obscuring the facts, preventing the public from accessing them and so fuelling public uncertainty. The inference was that irrational, fictionalized, biased and obfuscating campaigns signified a departure from the normative notions of rational, factually accurate and impartial journalism that contributes to reasonable debate and an informed citizenry. The prime minister also dismissed claims that government was putting the public at risk, claiming instead that robust, "elaborate" and technocratic processes ensured no GM products were released for sale or cultivation unless they had been tested and verified by "independent" scientists.

\section{Conclusion}

The campaigns continued for a year and did not subside until after a de facto retailer boycott had emerged, government had negotiated a voluntary moratorium with the industry on the cultivation of certain types of crops and Blair had apologized, conceding that the science underpinning GM food was uncertain with no clear evidence of harm or safety, risk or benefit. That is, until the government had clearly demonstrated its responsiveness to public concerns in a way that satisfied the media. The question, then, is what we can conclude about the differences between classic liberal and participatory approaches to the media from this case study.

Classic liberalism, emerging as it did in a context of political revolution, is concerned with the role of media in creating political stability and what professional attributes are required to ensure that a free press does not undermine this. From this emerged three roles for the media: as a watchdog on political abuse when the corruption of politicians threatened to incite public anger; as provider of accurate facts so that citizens could make informed political choices at elections; and as a 
forum for critical-rational debate. Ideas concerning what professional skills were needed to deliver this were rooted in the enthusiasm at the time for scientific method and rationality as an antidote to undue, volatile emotions that threatened stability. These values informed the emergence of a professional emphasis on objectivity, impartiality and factual accuracy. Thus there was an assumption that the ability of journalists to "report" from a distance, dispassionately and independently, was fundamental to their ability to hold governments to account and be neutral mediators of divergent views within discursive forums of critical-rational debate.

This article has argued that these values and assumptions have been fundamentally challenged and exposed in the new risk domains that provide much of the subject matter for environmental journalism. New risk disputes are able to challenge these because knowledge is contested, scientific methods are disputed and acrimonious disagreements emerge on how to proceed in conditions of uncertainty. The ability of the journalists to engage with these issues is further complicated by, on the one hand, the abstract, hypothetical and invisible nature of the risks; and, on the other hand, the "politically catastrophic" (Beck 1986) consequences of these and the deeply moralistic debates about the acceptability or otherwise of the risks. In the case of GM food, the bridge was constructed through critical interventions by credible figures (Prince Charles and Árpád Pusztai), in food as the embodiment of risk, in the parallels with other food scares such as BSE/CjD and in the familiar metaphoric associations of "guinea pigs" and "Frankenstein foods". The tension between the objective and polemical imperatives within newspapers constructions of their own identity became exposed. In the case of GM food, the newspapers veered towards the polemical - a shift that classic liberalism is unable to explore adequately without a prior dismissal of it as an aberration, a deviation from professional standards of objectivity, impartiality and independence.

A participatory approach to the media as outlined here offers one normative alternative to making sense of this. Rather than being concerned with political stability, such approaches are concerned with the revival of moribund democracies and the revitalization of politics. Rather than dispassionate "observers", the public interest imperative means that the media can legitimately become active participants seeking to influence policy change in their own right and to mobilize wider political participation. Rather than a pre-occupation with great affairs of the state such as political corruption, their primary role is to expose the impact of policies on everyday activities and, contrary to the claims of political elites, highlight the disempowerment of ordinary citizens to make choices over their own lives. Rather than holding governments to account, participatory media hold them to be responsive - not in a knee jerk way to those who shout the loudest, but in a way that includes in its consideration those views that oppose its own. Within such a framework, information is crucial - not as objective facts, but as contested knowledge and inconvenient details that those in power, both government and corporations, would rather pretend were certain or remained secret. Within the spaces of participatory media, emotion and reason become interwoven in debate rather than a duality; fear, anger, etc can be seen as legitimate expressions of political engagement rather than dismissed for tainting the critical-rational space of debate.

The framework outlined here raises substantive questions for exploration in subsequent articles; for instance, on how to address the potential abuses of a participatory media, what happens when the forms of revitalization are so destabilizing as to risk the future of the polity, what inadequacies a critique of these approaches might highlight, and whether other approaches in modern political and 
democratic theory might offer more useful alternatives. The intention here was not to address these but to offer a starting point for further discussion based on the argument that environmental journalism with its new risk-type subject matter has exposed the limitations of some of the core premises in media studies, a field still overly reliant on the outdated assumptions of classic liberalism. Thus, the central contention is that it is not the redrawing or blurring of the boundaries of journalism's established demarcations that are needed but a wholesale relocation of the premises underpinning notions of the ideal role of the media and professional journalism. The issue, then, is where might the normative dimensions of media engagement with the major socio-political and economic issues of late modernity be more usefully relocated.

\section{References}

Austin, Alison. and Lo, Helen. (1999). Evidence to the House of Commons Science and Technology Committee Scientific Advisory System: Genetically Modified Food. London: Sainsbury's.

Beck, Ulrich. (1986 (1992)). Risk Society: Towards a New Modernity (M. Ritter, trans.). Los Angeles, London, New Delhi and Singapore: Sage.

Beck, Ulrich. (1999). World Risk Society. Cambridge: Polity.

Beck, Ulrich. (2003). "Risk Society". In M. Slattery (ed.), Key Ideas in Sociology New York: Nelson Thornes.

Birks, Jen. (2009). Newspaper Campaigns, Publics and Politics. Glasgow: Glasgow University. PhD Thesis.

Blair, Tony. (1999). "GM foods: We Stand Firm". Daily Telegraph. 20 February. p.12

Blair, Tony. (2000a). 'The Key to GM is its Potential, Both for Harm and Good'. Independent on Sunday. 27 February. p. 28.

Blair, Tony. (2007). "Blair's Speech on the Media". The Times, 12 June, accessed 30 November 2010, available at http://www.timesonline.co.uk/tol/news/politics/article1922074.ece?token=null\& offset=0\&page $=1$.

Conboy, Martin. (2006). Tabloid Britain: Construction of Community through Language. London: Routledge.

Cottle, Simon. (1998). "Ulrich Beck, 'Risk Society' and the Media: A Catastrophic View?" European Journal of Communication, 13(1), pp. 5-32.

Cunningham, Brent. (2003) "Re-thinking Objectivity". Columbia Journalism Review. July/August, accessed 27 November 2010, available at:

http://www.alternet.org/media/16348.

Curran, James. and Seaton, Jean. (eds) (2003). Power without Responsibility. London and New York: Routledge.

Daily Mail (1998a). "Dangerous Food”, 11 August. p. 10.

Daily Mail (1999). "An Issue of Concern to Every Reader”, 06 February. p. 12.

Dryzek, John, Honig, Bonnie. and Phillips, Anne. (eds) (2006). The Oxford Handbook of Political Theory. Oxford: Oxford University Press.

Eilders, Christiane. (2002). "Conflict and Consonance in Media Opinion: Political Positions of Five German Quality Newspapers". European Journal of Communication, 17(1), pp. 25-63.

Express (1998a). "End Doubts on Food Safety", 10 August. p. 10.

Express (1998b). "Food Safety's Hard to Swallow", 09 June, p. 10.

Express (1998c). "The Hidden Dangers of 'Frankenstein Food”', 29 June, p. 10. 
Express (1998d). "Was professor right?", 14 August, p. 25.

Express (1999). "We Must Give a Lead over GM Foods", 13 February, p. 10.

Firmstone, Julie. (2008). "The Editorial Production Process and Editorial Values as Influences on the Opinions of the British Press towards Europe". Journalism Practice, 2(2), pp. 212-29.

Giddens, Anthony. (1998). "Risk Society: the Context of British Politics". In Jane Franklin (ed.), The Politics of Risk Society. Cambridge: Polity.

Greenslade, R. (2004). Press Gang: How newspapers make profits from propaganda. Basingstoke: Pan Macmillan.

Habermas, Jurgen. (1989 (1962)). The Structural Transformation of the Public Sphere (T. Burger, trans.). Cambridge: Polity.

Habermas, Jurgen. (1992). "Further Reflections on the Public Sphere". In Craig Calhoun (ed.), Habermas and the Public Sphere. Cambridge, MA and London: MIT Press.

Hargreaves, Ian. (2003) Journalism - Truth or Dare?. Oxford: Oxford University Press.

Hargreaves, lan and Lewis, Justin. (2003). Science and the Media: Towards a Better Map. London: ESRC.

Harrison, Tom. (1998). "Genetic Crop Scare Scientist Suspended". Mirror, 13 August. p. 11.

Held, David. (2006). Models of Democracy (3rd edn). Stanford: Stanford University Press.

Henry, Frances and Tator, Carol. (2002). Discourses of Domination: Racial Bias in the Canadian English-Language Press. Toronto: University of Toronto Press.

Howarth, Anita. (2010). "Contested Processes, Contested Influence: A Case Study of Genetically Modified Food In Britain". In Katrin Voltmer and Sigrid KochBaumgarten (eds.), Public Policy and the Mass Media: The Interplay of Mass Communication and Political Decision Making. London: Routledge.

Howarth, Anita. (2012, forthcoming). "Newspaper Campaigns as Media Interventions". In Kevin Howley (ed.), Media Interventions._New York: Peter Lang.

Independent on Sunday (1999). "Act now on GM", 07 February, p. 24.

Ingham, John. (1998). "Professor who Exposed Food Risk is Sacked". The Express, 13 August, p. 2.

Kaminsky, John.P. (2006) James Madison: Champion of Liberty and Justice. Madison, WI: Parallel Press.

Kitzinger, Jenny. and Reilly, Jacqui. (1997). "The Rise and Fall of Risk Reporting: Media Coverage of Human Genetics, Research, 'False Memory Syndrome' and 'Mad Cow Disease'”. European Journal of Communication, 12(3), pp. 319-50.

Locke, S. (2001). "Sociology and the Public Understanding of Science: from Rationalization to Rhetoric". British Journal of Sociology, 52(1), pp. 427-91.

Mirror (1999). "Label Frankenstein Food: Mirror's 'Label it all' Plea”, 15 February, p. 2.

Mindich, David. (2000) Just the Facts: How "Objectivity' ' Came to Define American Journalism. New York: New York University Press.

Neuzil, Mark. and Kovarik, William. (1996). Mass Media \& Environmental Conflict: America's Green Crusades._Thousand Oaks, New Delhi and London: Sage.

Neuzil, Mark. (2008). The Environment and the Press: From Adventure Writing to Advocacy._Evanston: Northwestern University Press. 
Pellizzoni, Luigi. (2003). "Uncertainty and Participatory Democracy”. Environmental Values, 12(2), pp. 195-224.

Pusztai, Arpad. (2002). "GM Food Safety: Scientific and Institutional Issues". Science as Culture, 11(1), pp. 69-92.

Richardson, John. D. and Lancendorfer, Karen. M. (2004). "Framing Affirmative Action: The Influence of Race on Newspaper Editorial Responses to the University of Michigan Cases". Harvard International Journal of Press/Politics, 9(74), pp. 74-94.

Teorell, Jan. (2006). "Political Participation and Three Theories of Democracy: A Research Inventory and Agenda". European Journal of Political Research. 45(5), pp. 787-92.

Thomas, James. (2005). Popular Newspapers, the Labour Party, and British Politics. London: Routledge.

Van Dijk, Teun. A. (1996). "Power and the News Media". Political Communication in Action. accessed 16 February, 2010, available at

http://www.discourses.org/OldArticles/Power\%20and\%20the\%20news\%20me dia.pdf.

Yearley, Stephen. (1991). The Green Case: A Sociology of Environmental Issues, Arguments and Politics. London: Unwin Hyman.

\section{Notes on Contributors}

Anita Howarth: A.Howarth@kingston.ac.uk

Lecturer at Kingston University, London.

\section{Publication list}

Book chapters

Howarth, Anita (2010). 'Contested Processes, Contested Influences: A Case Study of Genetically Modified Food in Britain'. In S. Koch-Baumgarten and K. Voltmer (eds.), Public Policy and the Mass Media: The Interplay of Mass Communication and Political Decision Making. London: Routledge, pp. 143-61. Routledge/ECPR Studies in European Political Science ISBN 9780415485463.

Howarth, Anita (2008) 'Foreign Policy, Identity and the Media: Contestation over Zimbabwe'. In H. Hadland, E. Louw, S. Seanti and H. Wasserman (eds.), Power, Politics and Identity in Post Apartheid South Africa. Cape Town: HSRC, pp. 290311. ISBN 9780796922021. 